\title{
Application and Research on Macroscopic Identification of Bitumen and Graptolite in Shale and Reflectance Detection
}

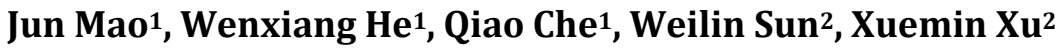 \\ ${ }^{1}$ Key Laboratory of Exploration Technologies for Oil and Gas Resources (Yangtze University), Ministry of Education, \\ School of Resources and Environment, Yangtze University, Wuhan, China \\ ${ }^{2}$ National Geology Experimental Testing Center, Beijing \\ Email: 1098435867@qq.com
}

How to cite this paper: Mao, J., He, W.X., Che, Q., Sun, W.L. and Xu, X.M. (2018) Application and Research on Macroscopic Identification of Bitumen and Graptolite in Shale and Reflectance Detection. Open Journal of Yangtze Gas and Oil, 3, 11-20. https://doi.org/10.4236/ojogas.2018.31002

Received: June 12, 2017

Accepted: January 28, 2018

Published: January 31, 2018

Copyright $\odot 2018$ by authors and Scientific Research Publishing Inc. This work is licensed under the Creative Commons Attribution International License (CC BY 4.0).

http://creativecommons.org/licenses/by/4.0/

\begin{abstract}
Longmaxi Formation of Lower Palaeozoic Silurian System in Northwest of Guizhou Province is an import target layer of shale gas exploration; the study of its organic matter maturity is a necessary indicator for evaluating the resources of shale gas. Because the Longmaxi shale does not contain any vitrinite; its thermal evolution must be tested by the shale asphalt reflectance and the graptolite reflectance. The DM4500 microscope is used to test the shale of Graptolite reflectance and asphalt reflectance. The results show that the shale graptolite reflectance is between $2.91 \%-3.20 \%$, average $3.08 \%$; asphalt fragments reflectivity is between $2.93 \%-3.19 \%$, average $2.94 \%$; amorphous bitumen reflectance is between $2.89 \%-3.18 \%$, average $2.89 \%$. Graptolite reflectance is slightly higher than the reflectance of asphalt. The average of equivalent vitrinite reflectance is $2.06 \%$; the equivalent vitrinite reflectance of asphalt debris is $2.20 \%$, indicating that the shale of Northwest Guizhou Silurian Longmaxi has been in high-over mature stage of thermal evolution. The result of study provides a reliable parameter for the evaluation of shale gas resources in the area, and also shows the applicability of the evaluation of bitumen and graptolite reflectance of the maturity of organic matter of shale gas in the Silurian System.
\end{abstract}

\section{Keywords}

Bitumen Reflectance, Graptolite Reflectance, Equivalent Vitrinite Reflectance, Microscopic Components, Longmaxi Formation

\section{Introduction}

Shale gas is an important field for current oil and gas exploration, as the huge 
resources of nonconventional natural gas, there exists the highest potential for the study of the black shale in the lower Palaeozoic Erathem of South China. In recent years, a great number of researches have been performed on the marine shale in Longmaxi Formation in the periphery areas of Sichuan Basin and in the southeast of Guizhou Province [1] [2] [3].

The result shows that the shale in Longmaxi Formation is a critical gas source zone in South China. It contains high organic matter; the thickness of high quality shale with TOC value higher than $2 \%$ is generally 10 to $50 \mathrm{~m}$, the type of organic matter is mainly Type I (Its equivalent vitrinite reflectance average $R_{\mathrm{o}}$ is between $2.0 \%-3.6 \%$ ) [4]. It is characterized by high organic matter abundance and high maturity.

The understanding of geological features of marine shale in Longmaxi Formation belonging to the northwest of Guizhou Province is weaker at present. The successful exploration and development of the same set of shale bed in the periphery area promotes the evaluation of shale stratum in Longmaxi Formation.

The thermal evolution maturity of organic matter is not only an important parameter for the evaluation of conventional source rocks, but also an indispensable geochemical indicator for unconventional shale gas research. In the early Palaeozoic strata, it commonly lacks vitrinite, but more graptolites, bitumen debris were developed, and amorphous bitumens were packed in fractures. The difference between the microscopic shapes is the foundation for detecting the reflectance of different microscopic components.

\section{Process of Samples and Experimental Test}

\subsection{Process of Samples}

The samples for detecting the reflectance for microscopic components are taken from black shale zone in Longmaxi Formation of Lower Silurian System of Qilong Village in Xianyuan Town, Xishui County, Guizhou Province. The sampling interval is about $2 \mathrm{~m}$, which is evenly distributed. The bulk samples are screened through slight breaking and grinding, the screened samples of 10 to 20 meshes (its particle size of 2 to $0.9 \mathrm{~mm}$ ) are poured into a special mold for bonding with epoxy resin, thus a round sample of $2 \mathrm{~cm}$ is created, and a bright surface with dense rock sample particle arrangement is developed after grinding and polishing.

\subsection{The Microscopic Characteristics of Organic Matters}

A whole rock slice microscopic observation is performed on rock samples from Longmaxi Formaiton in the studying area, from which 2 important and the highest content of microscopic components containing the graptolite and solid bitumen are found out. According to the different shapes of bitumens, they can also be divided into debris bitumen debris and amorphous bitumen. 


\subsubsection{The Microscopic Characteristics of Graptolites}

Under the microscope, it can be observed that the graptolitic chips are originated from their periderm organizations [5], they have the features of non-fluorescence, in the reflected light, the graptolite is in 2 shapes, particulate (inserted shape) and non-particulate (homogenous shape) shapes. The particulate graptolite is coarse, with multi-pores on its surface. It is often inserted with metallic minerals, and its measured reflectance is slightly small because it is affected by matrix. While the other mineral particles, the non-particulate graptolite, is smooth and even on its surface. Their reflectance is generally larger [6], and they appear a stronger convergence.

The graptolites in Longmaxi Formation are mainly dispersed in chips in the mineral matrix of shales. Compared with solid bitumen, their particle size is generally larger; mostly their shapes are not complete, some of them with good shapes are distributed in the matrix in long tubular and strip shapes (Figure 1(a)). A more geometrical outside residual shell is well maintained (Figure $1(\mathrm{~b}))$.
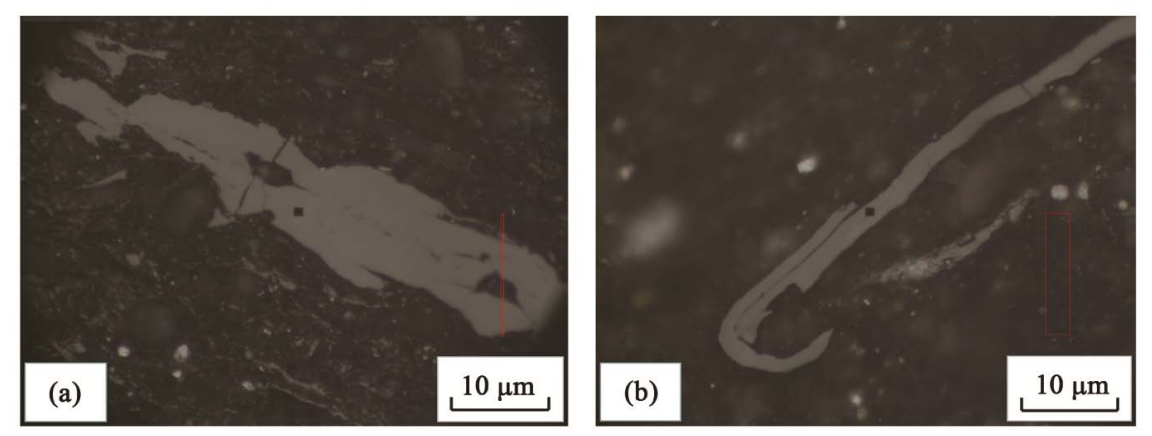

Figure 1. The characteristics of microscopic identification of graptolite (oil immersion). (a) Sample No: ql-2, from Longmaxi Formation, the microscopic characters of grapto lite:in strip and tubular shapes, the surface is smooth and more homogeneous; (b) Sample No: ql-2, from Longmaxi Formation, the microscopic characters of grapto lites: the outside residual shell is well maintained in thin strips, the surface is smooth and more homogeneous.

The non-particulate graptolites and less amount of particulate graptolites are mainly developed in the shale cores obtained from Longmaxi Formation, to ensure the convergence of tested results and more accurate testing results. In the study, non-particulate and homogeneous graptolites are mainly chosen for reflectance determination.

\subsubsection{The Microscopic Characteristics of Bitumen}

Bitumen generally has the same microscopic optical characteristics with graptolites, therefore it cannot be identified based on its optical characteristics. The morphological difference is a major attribute for bitumen's microscopic identification. There exists 2 morphological distributions of bitumen in shale from Longmaxi Formation in the studied area. For an easy division, it is defined as 
Bitumen A and Bitumen B.

The microscopic observation indicates that Bitumen $\mathrm{A}$ is in a shape of polygonal chip, and it appears in geometrical shape (Figure 2(a)). It possibly comes from a thermal evolution product of early bitumen in the source rock, and it is even with a smooth surface. Its particle size is from several $\mu \mathrm{m}$ to tens of $\mu \mathrm{m}$. The feafure of larger particles of Bitumen A provides easy identification of its reflectance; it is dispersedly distributed with lower content in Longmaxi Formation of the studied area.

Bitumen B is mainly filled in the micro-fractures of shale or the pores of mineral matrix (Figure 2(b)). It is without geometrical shape, mostly in a flowing status. It can be reflected that Bitumen $B$ is filled into the mineral pores at later stage through a certain distance of migration, which is called an bitumen formed in the late period [7]. Bitumen B is different from Bitumen A, because it is widely distributed with very small particles, and difficult for identification under the microscope. Therefore larger particles (the particle size is generally $>5 \mu \mathrm{m}$ ) should be chosen for reflectance determination as far as possible.
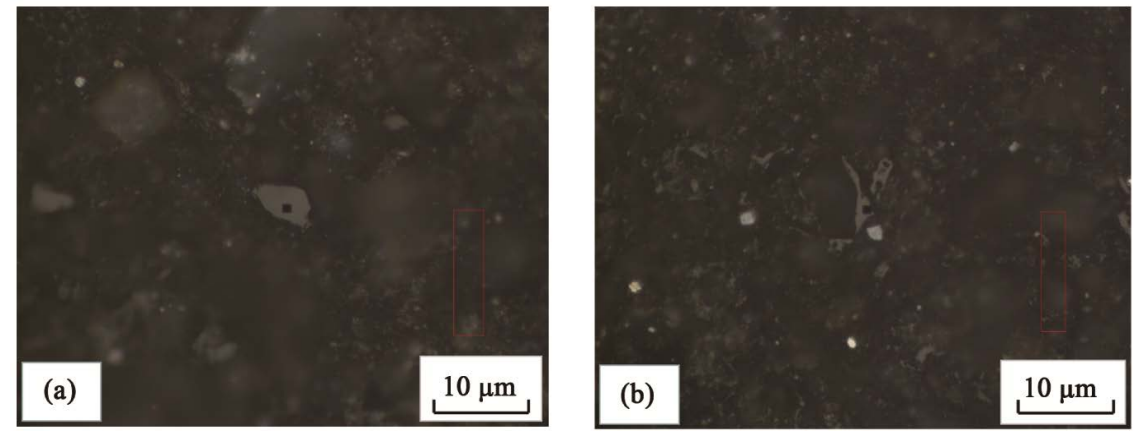

Figure 2. The identification of microscopic characteristics of Bitumen A and Bitumen B (oil immersion). (a) Sample No: ql-2, from Longmaxi Formation, the microscopic characters of Bitu men A: in chips, it is dispersedly distributed, the surface is smooth and more homogeneous; (b) Sample No: ql-2, from Longmaxi Formation, the microscopic characters of Bitumen B: it is filled into the pores of mineral particles and often enveloped in the periphery of mineral particles, the particles are smaller and are difficult for identifying under microscope.

\subsection{Sample Testing}

The experimental testing data are taken from the laboratory of China National Geological Experiment Center. The reflectance is measured by using Leica DM4500P polarizing microscope (the objective amplification is $510 \times$, oil immersion condition, the measuring point is no less than 20 for each sample); the result is taken from random reflectance value.

The bitumen particles are very small in shale, therefore the method of greyscale value for organic matter detection is used for reflectance calculation [8]. Before the measurement of samples, the reflectance and grey value of a standard materials are used for a linear regression. A reference method is provided for 
reflectance calculation based on regression, and it is also used for the calibration of instruments for ensuring the stability and reliability (the reflectance of the chosen standard materials are $0.59 \%, 0.90 \%, 1.2 \%, 3.17 \%, 5.21 \%$ respectively). According to the size of organic matters, each measuring point includes different number of pixels (64 to 4096). The grey-scale values of all the pixels are taken as reflectance values of the measuring points. The reflectance of different organic components (graptolite, bitumen debris and amorphous bitumen) in the shale samples are detected respectively; the histogram of reflectance value distribution of each microscopic component is obtained (the test result is taken from
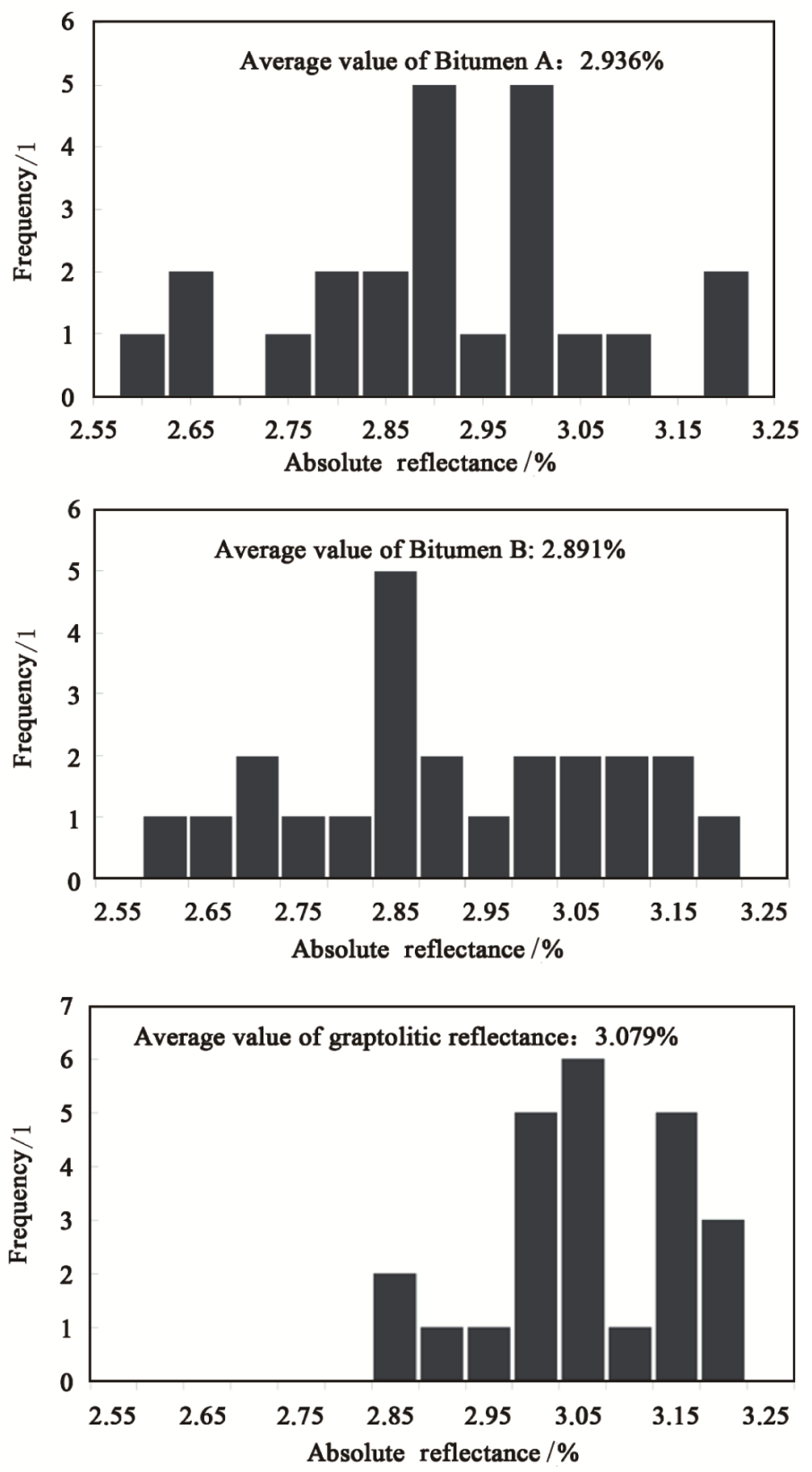

Figure 3. The histogram of reflectance in each microscopic component of shale in Longmaxi Formation of Qilong Village (rock sample ql-2). 
sample ql-2), and the average value of each microscopic component is calculated (Figure 3). The result of tested reflectance of microscopic component is shown below.

\section{The Result and Application of Reflectance Measurement of Microscopic Components}

The results of tested reflectance of microscopic components in the shale samples from Longmaxi Formation are summarized and appropriate equivalent vitrinite reflectance model is used for solution (Table 1).

Table 1. The conversion result of tested reflectance and equivalent vitrinite reflectance of the microscopic component of rock sample from Longmaxi Formation of Qiling Village.

\begin{tabular}{|c|c|c|c|c|c|c|}
\hline \multirow{2}{*}{ Sample No. } & \multicolumn{4}{|c|}{$\begin{array}{l}\text { Measured reflectance } \\
\text { value for each microscopic } \\
\text { component } \%\end{array}$} & \multirow{2}{*}{$\begin{array}{c}\text { Graptolitic } \\
\text { equivalent } \\
\text { vitrinite } \\
\text { reflectance } \\
\text { (Cao Changqun) } \\
/ \%\end{array}$} & \multirow{2}{*}{$\begin{array}{c}\text { Equivalent } \\
\text { vitrinite } \\
\text { reflectance } \\
\text { of Asphalt A } \\
\text { (Jacob)/\% }\end{array}$} \\
\hline & Asphalt B & Asphalt A & Graptolite & $\begin{array}{l}\text { Graptolite } \\
\text { Max }\end{array}$ & & \\
\hline ql-2 & 2.89 & 2.93 & 3.07 & 3.22 & 2.04 & 2.18 \\
\hline ql-6 & 2.44 & 2.54 & 2.91 & 3.12 & 1.99 & 1.91 \\
\hline ql-9 & 3.13 & 3.19 & 3.00 & 3.21 & 2.04 & 2.33 \\
\hline ql-11 & 3.18 & 3.12 & 3.20 & 3.46 & 2.17 & 2.37 \\
\hline $\mathrm{ql}-12$ & 2.95 & 3.01 & 2.99 & 3.20 & 2.03 & 2.22 \\
\hline
\end{tabular}

Obviously, there exists difference in the test results of 3 microscopic components that experienced the evolution of the same geological history. It is indicated that because of the difference of sensitivity to the temperature, the evolutional velocity is variable in different microscopic components in the same temperature condition. As a whole, the reflectance of Bitumen B ranges from 2.89\% to $3.18 \%$; the reflectance of Bitumen A ranges from $2.93 \%$ to $3.19 \%$, while the reflectance of graptolite is mainly concentrated from $2.91 \%$ to $3.20 \%$. The tested reflectance of Bitumen A and graptolite are on the average higher than that of Bitumen B. The graptolite, Bitumen A and Bitumen B are from the original organic matters of different chemical components. They have different response characteristics of the thermal effect, because there exists the difference in chemical components. The microscopic test of graptolite, that is, the periderm organization of graptolite, has higher aromaticity compared with the reflectance [6], which would possibly cause a more quicker thermal evolutional rate to the periderm organization of graptolite than that of reflectance. As they experience the same thermal history, the tested periderm reflectance of graptolite is much higher. When the asphalt is at the lower maturity stage, its thermal evolution rate is lower than that of the reflectance. When it is at high-over high maturity 
stage, it has a relatively quick thermal evolution rate. On the other hand, the reflectance of Bitumen A and graptolite are closer and higher than that of Bitumen $\mathrm{B}$, which is possibly because Bitumen A and graptolite experience the same geological evolutional history. However, the lower reflectance of Bitumen B is possibly because it experiences a shorter geological evolutional time.

On the other hand, the reflectance of Bitumen A and graptolite is more closed, and higher than that of Bitumen B. It is possible because Bitumen A and graptolite experience the same geologic evolutional history, while for the low reflectance of Bitumen $\mathrm{B}$, it is possible because the geologic evolutional history that Bitumen $B$ experiences is relatively short. In consideration of the situation that Bitumen $B$ is the most flowing and amorphously distributed in the fractures of mineral matrix under microscope, it is speculated that Bitumen B is located in shale fractures through migration and filling at the late stage.

The measured value of graptolitic reflectance has strong convergence, the convergence of Bitumens A and B is the next (Figure 1). The reason is that the microscopic characteristics of graptolite is evident; its contour is well maintained and easy for identification. Bitumen A and Bitumen B are in small particles; their morphology is unclear and the graptolitic fregment is easy to be confused with Bitumen A. There exists obvious difference in measured reflectance of Bitumens A and B in ql-6 rock sample, which indicates that the organic matter maturity has certain inhomogeneity in the process of geologic evolution.

In summary, to truly and reliably characterize the thermal evolutional process of black shale in Longmaxi Formation, in the study, the reflectance of Bitumen A and graptolite are equivalently calculated, and the difference between the 2 equivalent vitrinite reflectance is contrasted.

The condensation level of the aromatic structure of organic matter determines its reflectance [7], the conversion of equivalent vitrinite reflectance is actually in contrast with the aromaticity of different organic matters (graptolite and asphalt), and the vitrinites coexisted in the rock samples are to establish a mathematical relation model for both. In the actual study, different strata have different environments in geologic history where the development of biological population is unique, and different types of organics are sparingly coexisted in the same stratum. Therefore in the study, based on the summary of predecessors' empirical formulaes, appropriate conversional relation of vitrinite reflectance is chosen for the discussion of thermal evolutional level of shale in Longmaxi Formation of the research area.

At present, the vitrinites of graptolites are deeply studied by scholars both at home and abroad. Large numbers of studies are made by Cao Changqun [9] on the graptolitic reflectance in Ordovician-Silurian System, combined with the comprehensive geochemical parametric indexes, the evaluation indexes of the graptolitic reflectance on thermal evolutional level are determined, and related relation models are established for the graptolitic reflectance and equivalent vitrinite reflectance: 


$$
\lg V R_{\text {eq }}=0.572 \lg G R+0.021
$$

where, $V R_{\text {eq }}$ is the vitrinite reflectance, $G R$ is the graptolitic reflectance.

The correlativity between the graptolitic reflectance and the pyrolysis temperature of rocks in the source rocks of Cambrian-Silurian System was studied by Petersen et al. A model was established for the equivalent vitrinite reflectance of graptolite through the relation between vitrinite reflectance and rock pyrolysis temperature. But in the study, the vitrinite-like maceral from alga was mistaken with graptolite, therefore the measured graptolitic reflectance was unreliable, and the model could not be used to truly characterize the maturity of rocks. So in this study, the model established by Cao Changqun is chosen for calculating the equivalent reflectance of graptolite (Table 1).

For the wide existence of bitumen in source rocks, there is less study on the equivalent reflectance of bitumen [10]. In this study, the model of equivalent reflectance by Jacob is used for equivalent vitrinite reflectance conversion for the average value of reflectance for Bitumen $\mathrm{A}$ in different measured points of each rock sample (Table 1 ).

It can be known from Table 1, the distribution of equivalent reflectance of Bitumen A is from $1.91 \%$ to $2.37 \%$. It indicates that the source rock maturity is at high-over high level, which is closed to reported values in literatures [11], [12]. The distribution of equivalent reflectance of graptolite is from $1.99 \%$ to $2.17 \%$, which is lower, compared with the equivalent reflectance of Bitumen A. In principle, the consistence of both of the conversion results can more truly reflect the maturity of source rocks.

During the experimental process, for the purpose of reducing their testing errors, although the graptolite and bitumen can be distinguished based on the difference between their shapes, the anisotropy of optical property in graptolite will certainly affect their test results [13]. In addition, the samples used in the study are limited, which in an important factor affecting the test results, therefore there exist certain limitations in maturation of the reflected source rocks.

\section{Conclusions}

1) The Silurian Longmaxi shale does not contain any vitrinite, except for the enrichment of graptolites and asphalt; it provides the feasibility conditions for determining the degree of thermal evolution of hydrocarbon source rocks. The results show that the shale graptolite reflectance is between $2.91 \%$ - $3.20 \%$, average 3.08\%; asphalt fragments reflectivity is between $2.93 \%$ $3.19 \%$, average $2.94 \%$; amorphous bitumen reflectance is between $2.89 \%$ $3.18 \%$, average $2.89 \%$. Graptolite reflectance is slightly higher than the reflectance of asphalt.

2) The equivalent vitrinite of graptolite reflectance and equivalent vitrinite reflectance of asphalt debris is higher than 2.20 , indicating that the shale of 
Northwest Guizhou Silurian Longmaxi has been in high-over mature stage of thermal evolution. The equivalent vitrinite reflectance of asphalt is lower than the equivalent vitrinite of graptolite reflectance. The reason may be the Anisotropy of asphalt ort the samples. The equivalent vitrinite of graptolite reflectance and equivalent vitrinite reflectance of asphalt debris show the equal result, which can describe the maturity of shale more realistically. The further study of the reflectivity of Graptolite reflectance and the reflectance of asphalt will more effectively indicate the thermal evolution of organic matter characteristics.

\section{References}

[1] Zhang, J.C., Nie, H.K., Xu, B., et al. (2008) Geological Condition for Shale Gas Accumulation in Sichuan Basin. Natural Gas Industry, 28, 151-156.

[2] Nie, H.K. and Zhang, J.C. (2011) Types and Characteristics of Shale Gas Reservoir: A Case Study of Lower Paleozoic and around Sichuan Basin. Petroleum Geology and Experiment, 33, 219-225.

[3] Wu, L.M., Ding, W.L., Zhang, J.C., et al. (2011) Fracture Prediction of or Ganic-Enriched Shale Reservoirs in Lower Silurian Longmaxi Formation of the Southeastern Chongqing Area. Journal of Oil and Gas Technology, 33, 43-46.

[4] Gao, B. (2015) Geochemical Characteristics of Shale Gas in Lower Silurian Longmaxi Formation in Sichuan Basin and Its Geological Significance. Nature Gas Geoscience, 6, 1173-1182.

[5] Link, C.M., Bustin, R.M. and Goodarzi, F. (1990) Petrology of Graptolites and Their Utility as Indices of Thermal Maturity in Lower Paleozoic Strata in Northern Yukon, Canada. International Journal of Coal Geology, 15, 113-135. https://doi.org/10.1016/0166-5162(90)90007-L

[6] Bustin, R.M., Link, C.M. and Good Arzi, F. (1989) Optical Properties and Chemistry of Graptolite Periderm Following Laboratory Simulated Maturation. Organic Geochemistry, 14, 355-364. https://doi.org/10.1016/0146-6380(89)90001-6

[7] Yang, Y.F. (2016) Application of Bitumen and Graptolite Reflectance in Silu Rian Longmaxi Formation Shale, Southeastern Sichuan Basin. Petroleum Geology and Experiment, 4, 466-472.

[8] Schoenherr, J., Littke, R., Urai, J.L., et al. (2007) Polyphase Thermal Evolution in the Infra-Cambrian Group (South Oman Salt Basin) As Deduced by Maturity of Solid Reservoir Bitumen. Organic Geochemistry, 38, 1293-1318. https://doi.org/10.1016/j.orggeochem.2007.03.010

[9] Cao, C.Q., Shang, Q.H. and Fang, Y.T. (2000) The Study of Graptolite Reflectance as the Source-Rock Maturation in Ordovician and Silurian, Tarim Basin, Ordos, Jiangsu Area. Acta Palaeontology Sinica, 39, 151-156.

[10] Jacob, H. (1989) Classification, Structure, Genesis and Practical Importance of Natural Solid Bitumen (“Migra Bitumen”). International Journal of Coal Geology, 11, 65-79. https://doi.org/10.1016/0166-5162(89)90113-4

[11] Petersen, H.I., Schovsbo, N.H. and Nielsen, A. (2013) Reflectance Measurements of Zooclasts and Solid Bitumen in Lower Paleozoic Shales, Southern Scandinavia: Correlation to Vitrinite Reflectance. International Journal of Coal Geology, 114, 1-18. https://doi.org/10.1016/j.coal.2013.03.013 
[12] Guo, T.L. and Liu, R.B. (2013) Implications from Marine Shale Gas Exploration Breakthrough in Complicated Structural Area at High Thermal Stage: By Taking Longmaxi Formation in Well JY1 as an Example. Nature Gas Geoscience, 24, 643651.

[13] Guo, T.L. and Zhang, H.R. (2014) Formation and Enrichment Mode of Jiaoshiba Shale Gas Field, Sichuan Basin. Petroleum Exploration and Development, 41, 28-36. https://doi.org/10.1016/S1876-3804(14)60003-3 